\title{
The last erosional stage of the Molasse Basin and the Alps
}

\author{
Fritz Schlunegger $\cdot$ Jon Mosar
}

Received: 15 January 2010/Accepted: 24 September 2010/Published online: 17 October 2010

(C) Springer-Verlag 2010

\begin{abstract}
We present a synoptic overview of the Miocene-present development of the northern Alpine foreland basin (Molasse Basin), with special attention to the pattern of surface erosion and sediment discharge in the Alps. Erosion of the Molasse Basin started at the same time that the rivers originating in the Central Alps were deflected toward the Bresse Graben, which formed part of the European Cenozoic rift system. This change in the drainage direction decreased the distance to the marine base level by approximately $1,000 \mathrm{~km}$, which in turn decreased the average topographic elevation in the Molasse Basin by at least $200 \mathrm{~m}$. Isostatic adjustment to erosional unloading required ca. 1,000 $\mathrm{m}$ of erosion to account for this inferred topographic lowering. A further inference is that the resulting increase in the sediment discharge at the MiocenePliocene boundary reflects the recycling of Molasse units. We consider that erosion of the Molasse Basin occurred in response to a shift in the drainage direction rather than because of a change in paleoclimate. Climate left an imprint on the Alpine landscape, but presumably not before the beginning of glaciation at the Pliocene-Pleistocene boundary. Similar to the northern Alpine foreland, we do not see a strong climatic fingerprint on the pattern or rates of exhumation of the External Massifs. In particular, the initiation and acceleration of imbrication and antiformal
\end{abstract}

F. Schlunegger ( $\square)$

Institute of Geological Sciences, University of Bern,

Baltzerstrasse 1+3, 3012 Bern, Switzerland

e-mail: schlunegger@geo.unibe.ch

\section{J. Mosar}

Department of Geosciences-Earth Sciences,

University of Friboug, Chemin du Musée 6,

1700 Fribourg, Switzerland

e-mail: Jon.mosar@unifr.ch stacking of the foreland crust can be considered solely as a response to the convergence of Adria and Europe, irrespective of erosion rates. However, the recycling of the Molasse deposits since $5 \mathrm{Ma}$ and the associated reduction of the loads in the foreland could have activated basement thrusts beneath the Molasse Basin in order to restore a critical wedge. In conclusion, we see the need for a more careful consideration of both tectonic and climatic forcing on the development of the Alps and the adjacent Molasse Basin.

Keywords Alps - Molasse - Geodynamics - Tectonics · Climate and erosion

\section{Introduction}

The Pliocene-modern history of the Alps and their northern foreland basin (Fig. 1) has recently been the focus of several papers (e.g., Cederbom et al. 2004; Willett et al. 2006; Vernon et al. 2008, 2009; Rosenberg and Berger 2009; Ziegler and Fraefel 2009) that aimed at exploring the controls of the more than twofold increase in sediment discharge at the Miocene-Pliocene boundary (Hay et al. 1992; Kuhlemann 2000; Kuhlemann et al. 2001). Willenbring and von Blanckenburg (2010) recently challenged the proposed scenario of increasing sedimentation rates. Based on the constant ${ }^{10} \mathrm{Be} /{ }^{9} \mathrm{Be}$ ratios of Late Miocene-modern offshore deposits, they inferred a constant erosional mass flux and interpreted the increased sediment discharge at the Miocene-Pliocene boundary as an artifact of chronostratigraphy and selective sediment preservation (e.g., Sadler 1999). However, the global curve for sediment preservation versus time, presented by Willenbring and von Blanckenburg (2010), underestimates the amount of Mio-Pliocene 
sedimentation in the Alps (Kuhlemann et al. 2001). This suggests that the increase in sedimentation since that time may be real, but not as pronounced as considered by previous authors. Cederbom et al. $(2004,2008)$ interpreted this increase to have occurred at the time that erosion of the Molasse Basin started, and active deformation became focused in the core of the Alps where Quaternary thrusts were mapped (Persaud and Pfiffner 2004; Ustaszewski and Pfiffner 2008). Cederbom et al. (2004) suggested that this increase in erosion was a response to the onset of the Gulf Stream and the resulting wetter and more erosive climate in continental Europe. In contrast, Willett et al. (2006) proposed a control on the southern side of the Alps. They suggested that the onset of acceleration in erosional flux was initiated in response to a lowered base level resulting from the Messinian salinity crisis and when a more humid climate increased erosion in the Alps. Despite differences in the geodynamic concepts between these studies, both argue for a climate control and emphasize far-reaching consequences for the development of the orogen. In particular, Cederbom et al. (2004) interpreted that the net erosional unloading caused isostatic rock uplift of the foreland and increased exhumation rates in the Alps via flexural accommodation. In contrast, Willett et al. (2006) interpreted that accelerated erosional unloading of the orogen resulted in focused exhumation of the Penninic crystalline basement.

One major drawback in the reconstruction of relationships between climate and erosion is the lack of a strong and distinct signal of a climate change at the Miocene-
Pliocene boundary. Although climate proxies from both the Pacific (Zachos et al. 2001) and the continental records (Cerling et al. 1997; Bruch et al. 2006) do suggest a cooling trend between the Late Miocene and the Pliocene, this paleoclimate shift was gradual rather than a discrete single event (Cerling et al. 1997). Furthermore, in the Aar Massif (Fig. 2), acceleration of exhumation started prior to $5 \mathrm{Ma}$ in its present topographic culmination (Vernon et al. 2008) and can thus not be related to a possible climate change at the Miocene-Pliocene boundary (Cederbom et al. 2004). Given these yet unresolved issues, we decided to discuss alternatives to climate change to explain the rock uplift beneath the Molasse Basin. Inspired by the work of Ziegler and Fraefel (2009), we focused our attention to the idea that erosion of the Molasse Basin was driven by changes in the flow direction of the Alpine rivers. We present a discussion of published data on the Late Miocene-recent erosion of the Molasse Basin together with the restorations of its drainage pattern.

We emphasize that this work does not question the validity of previous model-based investigations, only that the solution to the Molasse Basin erosion and the response of the Alps is non-unique. In particular, we present an alternative mechanism capable of explaining the erosion of the Molasse Basin as due solely to topographic adjustment to drainage network changes and the resulting isostatic response to erosional unroofing. This calls for a more careful consideration of tectonics and its interaction with climate and erosion as the driving mechanisms for Alpine evolution.
Fig. 1 a Location map of the Alps with respect to the European Cenozoic Rift system. $B F$ Black Forest, $B G$ Bresse Graben, FP Franconian Platform, $H G$ Hessian Graben, $L G$ Limagne Graben, $L R G$ Lower Rhine Graben, $U R G$ Upper Rhine Graben, $O W$ Odenwald, $V G$ Vosges (modified from Dèzes et al. 2004). b Simplified model for the oblique opening of the Rhine and Bresse Grabens and the connection across the transtensional Rhine-Bresse Transfer Zone (modified after Madritsch et al. 2010a)

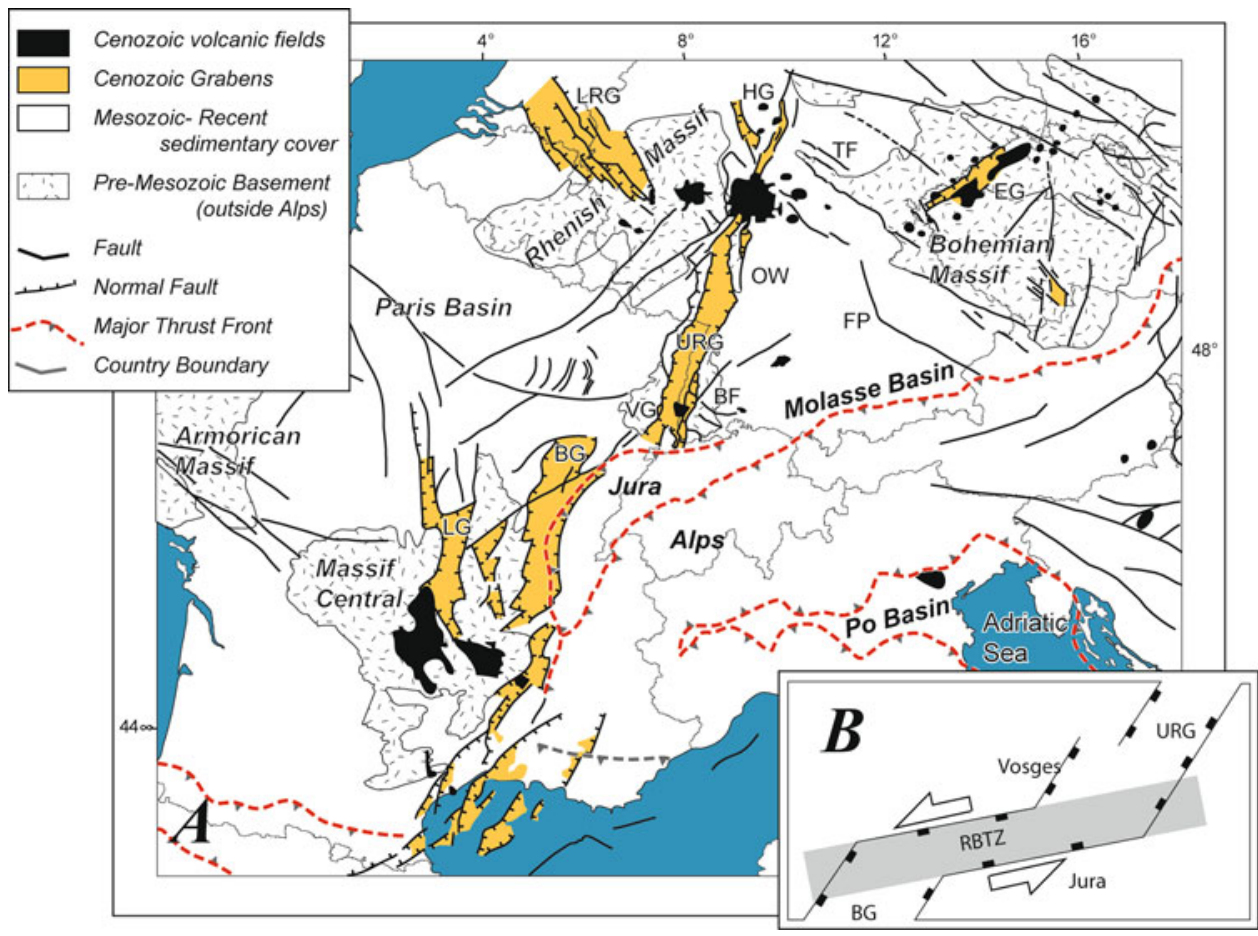




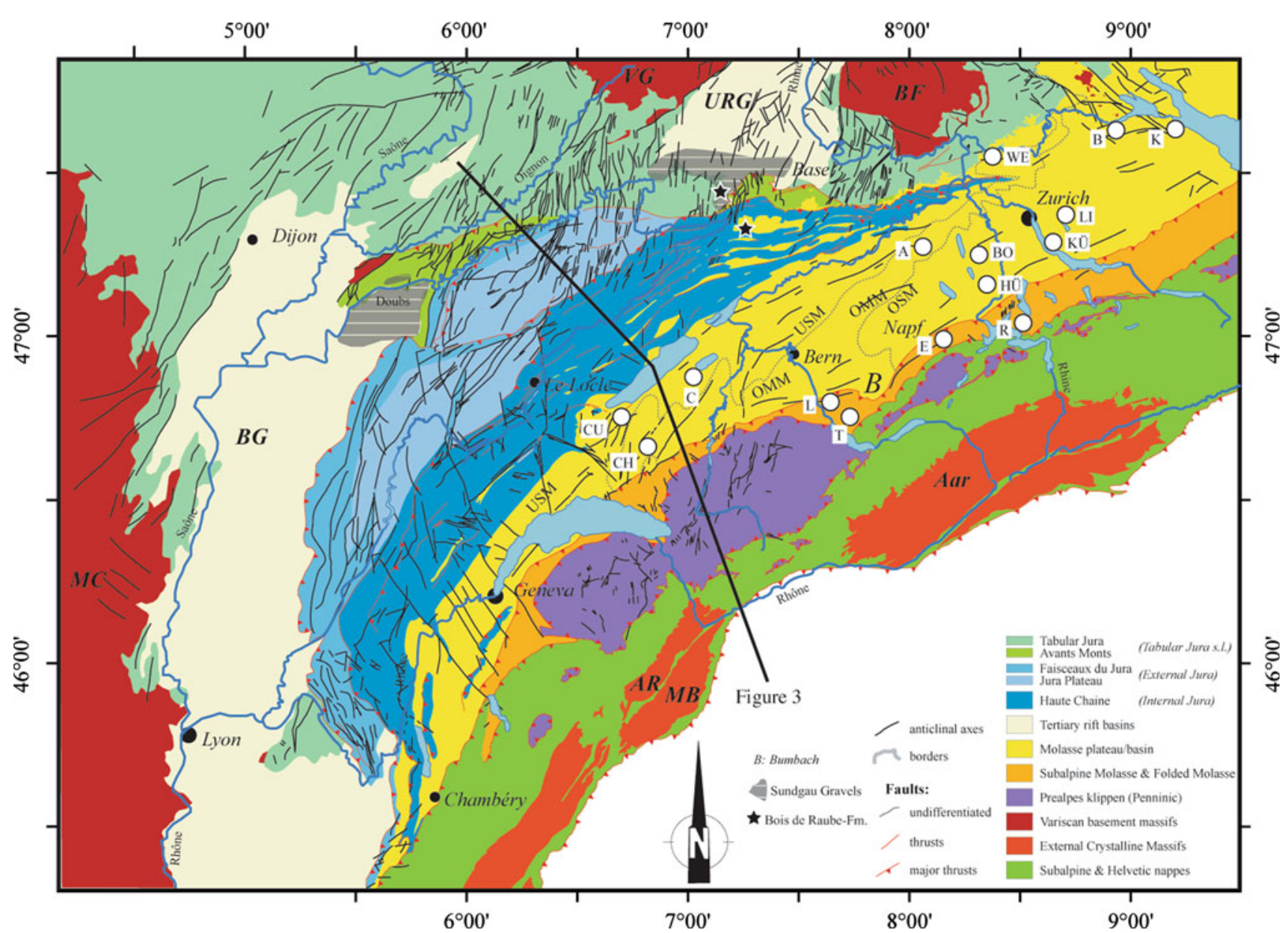

Fig. 2 Simplified geological map of the northern Alpine foreland with major structural units. Localities and stratigraphic sections discussed in text: $A$ Altishofen-1, $B$ Berligen-1, $B O$ Boswil-1, $C$ Courtion, $C H$ Chappelle-1, $C U$ Cuarny-1, $E$ Entlebuch-1; $H \ddot{U}$ Hünenberg-1, $K$ Kreuzlingen-1, $K \ddot{U}$ Küsnacht-1, $L$ Linden-1, LI Lindau-1, $R$ Rigi,
$T$ Thun-1, WE Weiach, $B$ Bumbach. Basement massifs: Aar Aar Massif, $A R$ Aiguilles Rouges Massif, $M B$ Mont Blanc Massif. Variscan basement massifs: $B F$ Black Forest, $M C$ Massif Central, $V G$ Vosges. $U R G$ Upper Rhine Graben, $B G$ Bresse Graben

\section{The Alps}

\section{Architecture}

The present-day tectonic architecture of the Central Alps (Figs. 2, 3) is typical for a doubly vergent orogen, with crystalline rocks of European upper crust that are exposed in the Penninic crystalline nappes and the External Crystalline Massifs. These latter units, of which the Aar and Mt. Blanc Massifs are well studied and prominent examples, form antiformal stacks of crystalline rocks and their Mesozoic sedimentary cover (Fig. 3; Schmid et al. 1996; Burkhard and Sommaruga 1998). These massifs evolved by Miocene and younger imbrication of the upper foreland crust while the lower crust was subducted (Schmid et al. 2004; Escher and Beaumont 1997; Escher et al. 1997; Kissling et al. 2006; Bonnet et al. 2007). South of the Aar Massif is the Penninic crystalline unit with a core of high-grade metamorphic basement. North of the External basement Massifs and their deformed cover nappes lies the Molasse Basin, which consists of a synorogenic clastic wedge that rests on Mesozoic sediments of the European carbonate platform (Pfiffner 1986; Homewood et al. 1986; Homewood and Lateltin 1988). The basin fill is folded and thrusted along its southeastern margin forming the Subalpine Molasse. The northwestern erosional margin of the basin is bordered by the Jura fold-and-thrust belt. Isolated remnants of the Molasse Basin are preserved in synclines of the folded Jura. Farther north, the Jura fold-and-thrust belt grades into the Plateau Jura and the Faisceau Lédonien area that over-rides the Bresse Graben margin (Fig. 2).

\section{Evolution}

The Alps evolved in response to collision of the Adriatic promontory of the African plate with the European 


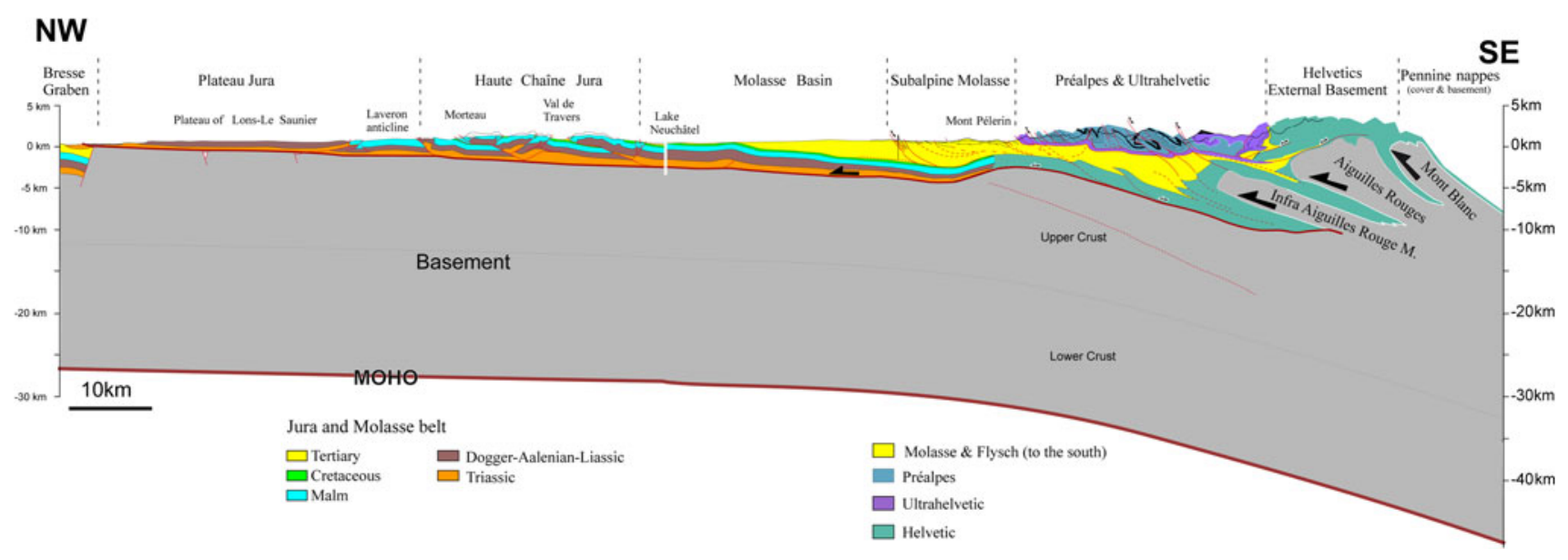

Fig. 3 Simplified NW-SE cross-section across the northern Alps and the foreland (modified from Sommaruga 1997; Mosar et al. 1996). Lines in the Molasse basin show the major present-day extent of the

continent. Collision involved the decoupling of the subducting slab from the Alpine nappe stack and tectonic underplating/accretion of European upper crust to the Alpine wedge (Escher and Beaumont 1997; Escher et al. 1997; Schmid et al. 1996, 2004; Dèzes et al. 2004). The development of antiformal stacks of basement thrust sheets of which the Aar and the Mont Blanc Massifs are prominent examples (Fig. 3) (Burkhard 1990; Laubscher 1992; Pfiffner et al. 1997a; Burkhard and Sommaruga 1998) occurred during the latest stage of Alpine development and accommodated only $30-35 \mathrm{~km}$ of a total of over $500 \mathrm{~km}$ of Alpine shortening (Schmid et al. 1996). Uplift and exhumation of the Aar Massif started during the Miocene (Burdigalian) and accelerated during the Tortonian $( \pm 10 \mathrm{Ma})$, some 5 Myear before the MiocenePliocene boundary (Michalski and Soom 1990; Pfiffner et al. 1997a; Fügenschuh and Schmid 2003; Vernon et al. 2008). Interestingly, accelerated antifomal stacking of the External Massifs was contemporaneous with decreasing exhumation rates in the Penninic nappes farther south (Vernon et al. 2008), reflecting a shift in the location of enhanced exhumation from the Penninic crystalline nappes to the External Massifs (Fügenschuh and Schmid 2003). Miocene and Early Pliocene imbrication and uplift of the External Massifs was accompanied by detachment and NW-translation of the Molasse Basin above an intraTriassic décollement horizon. This coincided with thinskinned deformation of the Jura fold-and-thrust belt some 50-80 km north of the front of the Alpine nappes (Buxtorf 1916; Laubscher 1961; 1992; Sommaruga 1997, 1999; Affolter and Gratier 2004; Dèzes et al. 2004). During Pliocene time, the Alpine deformation front, which also involved the basement, propagated northwestward into the Plateau Jura (Guellec et al. 1990; Pfiffner et al. 1997b; Ustaszewski and Schmid 2007). Accordingly, the
OSM, OMM, and USM. Outcrops of UMM are found in the Subalpine Molasse imbricates only. See Fig. 2 for location of crosssection

major thin-skinned deformation phase of the Jura between ca. 10 and $4 \mathrm{Ma}$ was followed by thin- and thick-skinned (Laubscher 1986; Mosar 1999; Ustaszewski and Schmid 2007; Madritsch et al. 2010a) deformation at low strain rates until recent times (Giamboni et al. 2004a, 2004b; Braillard 2006; Carretier et al. 2006; Madritsch et al. 2010a). Mosar (1999) suggested that this northward shift of basement deformation occurred in order to restore a stable orogenic wedge geometry as stacking of the External Massifs shifted the wedge to a supercritical state.

\section{The Molasse Basin}

The Oligocene to Miocene deposits of the Molasse Basin (Fig. 2) are the combined response to crustal thickening and surface erosion in the adjacent Alpine orogenic wedge (Pfiffner 1986; Burkhard 1990; Sinclair et al. 1991; Kuhlemann and Kempf 2002; Schlunegger et al. 2007). Four lithostratigraphic groups forming two coarsening-, thickening and shallowing-upward megasequences have been identified (Matter et al. 1980; Sinclair et al. 1991; Sinclair and Allen 1992). The first megasequence comprises the Rupelian Lower Marine Molasse unit (UMM) (Diem 1986) and the overlying Chattian to Aquitanian fluvio-lacustrine suite of the Lower Freshwater Molasse (USM) (Strunck and Matter 2002). The second megasequence, starting with the Burdigalian transgression of the Upper Marine Molasse (OMM), is made up of shallow marine deposits and fan deltas at the thrust front (Keller 1989). It is overlain by Serravalian fluvio-lacustrine conglomerates, sandstones and marls of the Upper Freshwater Molasse group (OSM). Note, we use the classical German abbreviations in this paper (Matter et al. 1980). 
At the northern margin of the Alps, Molasse deposits are intensely deformed into a stack of imbricate thrust sheets (Subalpine Molasse). A distinct back-thrust marks the deformation front of the Molasse. The section between this back-thrust and the imbricate thrust sheets is referred to as a 'triangle zone' as it displays a classical triangular geometry, which is found along strike in most of the Molasse Basin (Vollmayr and Wendt 1987; Gorin et al. 1993). Near Bumbach (Fig. 2), Haus (1937) mapped thrusts of the Subalpine Flysch and the Helvetic nappes that cut the thrusted Subalpine Molasse, indicated by an angular unconformity between Molasse units and the Helvetic nappes. A similar situation where the triangle zone is cut at a high angle by faults of the Subalpine Molasse was indentified by Haldemann et al. (1980). These observations point toward late syn-depositional thrusting and deformation resulting from backstepping of the Alpine deformation front from the Jura to the Subalpine Molasse. In support of this interpretation, Cederbom et al. (2004, 2008) reported partially annealed apatite fission track ages that are vertically offset by $0.6-0.8 \mathrm{~km}$ along the basal thrust of the Subalpine Molasse in the boreholes of Entlebuch-1 and Thun-1 (Fig. 2). Using these constraints, Cederbom and coauthors estimated thrusting in the order of ca. $2 \mathrm{~km}$ that occurred after $5 \mathrm{Ma}$ (von Hagke et al. 2010).

During the development of the Jura fold-and-thrust belt, the western part of the Molasse Basin evolved into a wedge-top basin (or negative-alpha basin according to Willett and Schlunegger 2010) that was detached above the Triassic evaporites (Laubscher 1961; Bonnet et al. 2007). In the western part of the Molasse Basin, a number of gentle anticlines and thrust-related folds developed within the basin (Sommaruga 1999). Farther westward, these folds are more prominent and subdivided the Molasse Basin into several sub-basins. Whether at least the initial development of these structures was syn-depositional is uncertain owing to intense late-stage erosional truncation of the Molasse series.

\section{The uplift and erosion of the Molasse Basin}

As the top of the Molasse sequence has been removed by erosion, the age of the end of deposition, the age of the onset of erosion, and the thicknesses of removed sections must be estimated by indirect methods. In the eastern parts of the Swiss Molasse Basin, the youngest preserved deposits are early Tortonian in age (Rahn and Selbekk 2007). Farther east in the German and Austrian parts of the Molasse Basin, the youngest preserved sediments are dated as 9-8 Ma (Kuhlemann and Kempf 2002). Erosion of the Swiss part of the Molasse Basin has classically been considered as response to the 10-4-Ma-major phase of shortening of the Jura fold-and-thrust belt. In particular, Ziegler and Fraefel (2009) considered that wedge-top emplacement of the Molasse Basin resulted in rock uplift and eastward tilting of its Swiss parts and in an eastwarddirected reversal of the drainage system. Similarly, in a review paper on the development of the Molasse Basin, Kuhlemann and Kempf (2002) considered that termination of sedimentation in the undeformed Molasse started in the western part in the course of uplift of the Swiss Jura Mountains after $11 \mathrm{Ma}$ and reached Lower Austria around 6-5 Ma. They interpreted that enhanced uplift of both the Alps and the Molasse Basin started at around $6 \mathrm{Ma}$ in the Swiss and Western Alps, and some Myear later in the Eastern Alps.

Magnitudes of erosion were estimated based on sonic and density logs (Kälin et al. 1992; Brink et al. 1992), depths of clay mineral alterations (smectite to mixed-layer transitions; Monnier 1982), and vitrinite reflectance data in wells that were drilled into the Molasse sequences (Schegg and Leu 1998). Porosity estimates (based on sonic and density logs) yielded $0-3 \mathrm{~km}$ of post-Miocene erosion (Kälin et al. 1992), but these methodologies have a relatively poor precision (Brink et al. 1992). Evaluations of transition zones of smectite to mixed-layer clays resulted in a more consistent and homogenous pattern of erosion that range from $1,000-1,200 \mathrm{~m}$ in the western and central sector of the Swiss Molasse Basin to $500 \mathrm{~m}$ farther east (Monnier 1982). Thermal modeling of vitrinite reflectance data from oil wells in the western Swiss Molasse Basin indicated 2-2.6 km of erosion in the Plateau Molasse and $4.3 \mathrm{~km}$ in the Subalpine Molasse (Schegg et al. 1997). In a regional study, Schegg (1993) used vitrinite reflectance values of $0.2-0.6$ from exposed Molasse deposits in the western, central, and eastern sectors to estimate ca. $2 \mathrm{~km}$ of erosion. Although the reflectance values vary in places, they reveal a similar average across the entire Molasse Basin (Schegg 1993), which implies little spatial variation of post-depositional erosion (Willett and Schlunegger 2010). For the northeastern border of the Swiss Molasse Basin (drill site Weiach, Fig. 2), Mazurek et al. (2006) estimated $750-1,050 \mathrm{~m}$ of erosion since $10 \mathrm{Ma}$ based on thermal modeling of apatite fission track ages in Paleozoic deposits underlying the Molasse and Mesozoic sequences.

Estimates of both the magnitude and particularly the time of Molasse Basin uplift and erosion were presented by Cederbom et al. (2004, 2008) based on the depths of annealed apatite fission track ages in several boreholes drilled in the Molasse Basin (Fig. 4b). According to these studies, the amount of erosion was uniform in the undeformed Molasse and ranges between 1 and $2 \mathrm{~km}$ across the entire basin, thus corroborating the uniform means of vitrinite reflectance values of exposed Molasse units 
(Schegg 1993). Also according to Cederbom et al. (2004, 2008), erosion started at ca. $5 \mathrm{Ma}$ in both the western and eastern sectors and occurred within a relatively short time interval of 2-3 Myear. Because of the identical time and magnitude of erosion in the entire Swiss Molasse Basin, Cederbom et al. $(2004,2008)$ concluded that its erosion is not entirely related to shortening of the Jura Mountains and wedge-top basin emplacement.

We prefer the erosional scenario of Cederbom et al. $(2004,2008)$ because it is not only based on quantitative estimates of the amount of erosion but also on the time of erosion. Whereas previous authors inferred the latter information from indirect evidence such as the spatial relationship between regions of maximum Jura shortening and oldest exposed Molasse units (e.g., Fig. 2), the thermo-chronometric data from Molasse deposits in deep drill holes (Cederbom et al. 2004, 2008) yielded the only independent age constraints on the time of uplift and erosion. Most important, the ages of Cederbom et al. (2004, 2008) are not biased by spatial relationships to the Jura. This allows the shortening of the Jura and the erosion of the Molasse to be discussed independently (e.g., Willett and Schlunegger 2010). In addition, Cederbom et al. $(2004,2008)$ presented erosional age estimates with the highest currently available resolution. Note that our preferred erosional scenario is in line with the exposure of progressively older Molasse deposits toward the west (Fig. 2). Indeed, the depositional age trend of the exposed Molasse sediments in the Plateau Molasse (i.e., increasingly older exposed sediments toward the southwest) can be considered to reflect non-uniform deposition since the Middle/Late Miocene (e.g., Willett and Schlunegger 2010) instead of a strong erosional gradient (e.g., Kuhlemann and Kempf 2002). Given a basin length of ca. $240 \mathrm{~km}$ and an average cross-sectional width of $50 \mathrm{~km}$, this amount of erosion yielded between 12,000 and $24,000 \mathrm{~km}^{3}$ of additional material (compared to the mass flux from the Alps) whose source was in the Molasse Basin (Fig. 4d).

The pattern of erosion rates as outlined above can be further detailed for the distal segment of the Swiss Molasse Basin north of Zurich (Fig. 4c). At Weiach (Fig. 2), Mazurek et al. (2006) estimated 750-1,050 m of erosion since $10 \mathrm{Ma}$ based on the thermal evolution of the underlying Paleozoic deposits. Near Weiach, >1.8-Ma-old fluvial gravels referred to as 'Höhere Deckenschotter' rest $175 \mathrm{~m}$ above the modern Rhine valley (Müller et al. 2002). If erosion started at $10 \mathrm{Ma}$ (Mazurek et al. 2006), then the corresponding erosion rates were ca. $100 \mathrm{~m} /$ Myear between 10-8 Ma, and $90 \mathrm{~m} /$ Myear thereafter. Using the more precise chronology of Cederbom et al. (2004) for basin erosion yields erosion rates of ca.
300-400 m/Myear between 5-3 Ma and $90 \mathrm{~m} /$ Myear since then (Fig. 4c).

\section{The central European rifts: Upper Rhine and Bresse Grabens}

The European Cenozoic rift system to the north and the west of the Alpine orogen (Figs. 1,2) crosses the continent from the North Sea to the Mediterranean (Ziegler 1992, 1994; Sissingh 1998; Dèzes et al. 2004; Ziegler and Dèzes 2005, 2007). Its southern branch includes the Gulf of Lions, Valence, Bresse and Limagne Grabens, whereas its northern branch is formed by the Upper and Lower Rhine Graben and the Hessian Depression (Fig. 1). The Bresse Grabens and Upper Rhine Grabens are linked by the RhineBresse Transfer Zone (RBTZ), a system of transtensional faults that accommodated the Eocene to present crustal extension by left-lateral slip (Fig. 1b); (Geissert et al. 1976; Petit et al. 1996; Giamboni et al. 2004a, b; Madritsch et al 2010a, 2010b).

For the Upper and Lower Rhine Graben, comprehensive syntheses of litho- and chronostratigraphic data were presented by Sissingh (1998, 2006a, 2006b) and Berger et al. (2005a, b). The Upper Rhine Graben, which contains up to 4,000 m of Cenozoic sediments, and the Hessian Depression started to subside during Middle Eocene time (Hinsken et al. 2007; Sissingh 2006b). In the course of the Late Eocene and Early Oligocene, rifting propagated into the Lower Rhine Graben. In the Upper Rhine Graben, Middle Eocene to Early Oligocene (Lutetian to lower Rupelian) series consist of basin marginal, locally derived conglomerates and lacustrine carbonates and of basinal shales and halites. During the late Rupelian and early Chattian, Alpine-derived sands were shed into the Upper Rhine Graben where they interfingered with marine shales. These clastics reached the Upper Rhine Graben via the Raurachian Depression that was controlled by faults extending SW-ward from the Upper Rhine Graben across the area of the future Jura fold-and-thrust belt and into the Molasse Basin (Berger et al. 2005a; Hinsken et al. 2007; Ziegler and Fraefel 2009). During the late Chattian, the communication between the Molasse Basin and the Upper Rhine Graben was interrupted again. While tensional subsidence of the northern parts of the upper Rhine Graben continued without interruptions to the present, its southern parts were uplifted by about $1,500 \mathrm{~m}$ during mid-Burdigalian time (18 Ma) in conjunction with the development of the Vosges-Black Forest Arch, involving lithosphere-scale folding (Ziegler et al. 2002; Dèzes et al. 2004; Ziegler and Dèzes 2007). Ford and Lickorish (2004) and Bourgeois et al. (2007) proposed that this topographic high represented the 


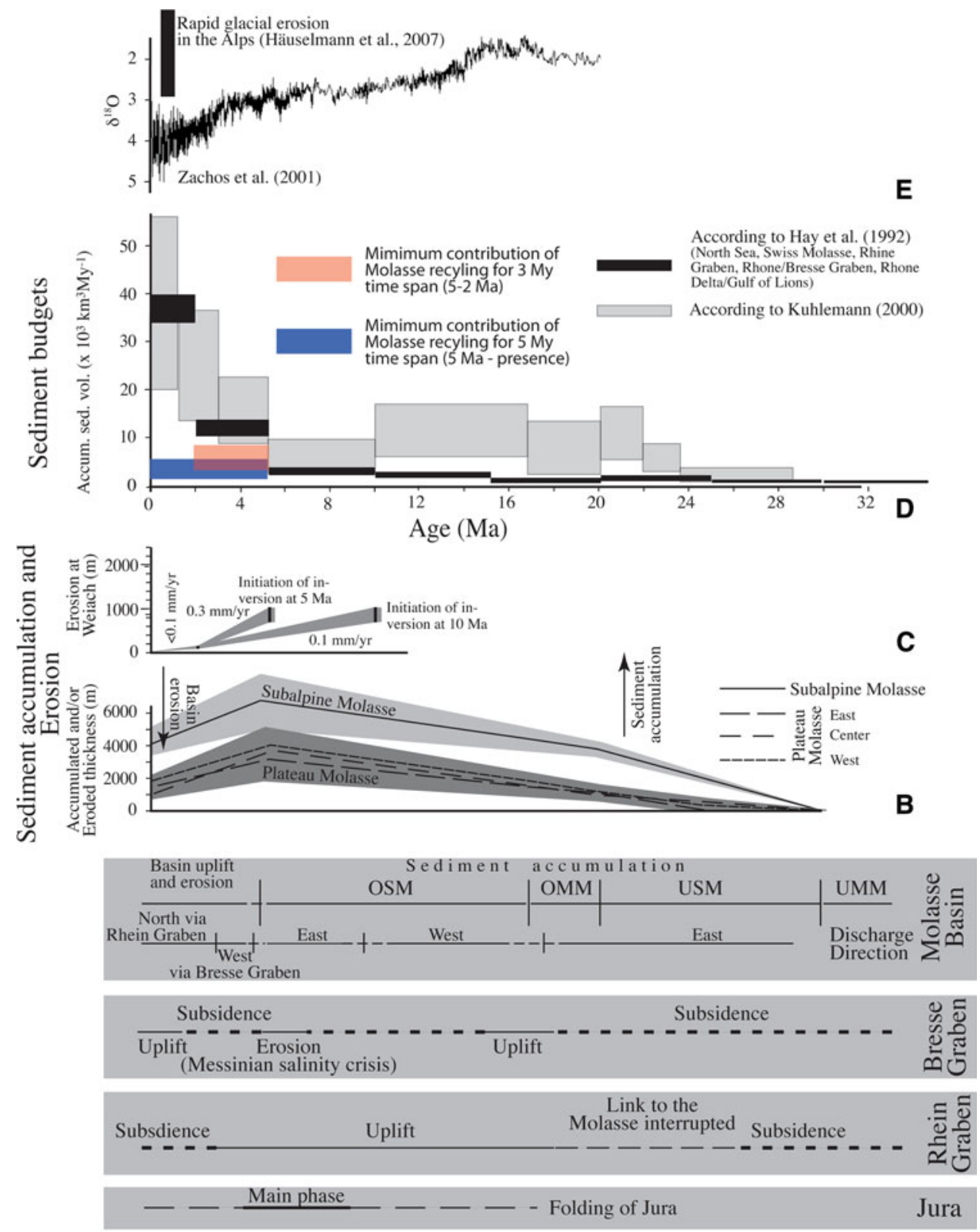

Fig. 4 a Chronology of (i) sediment accumulation and erosion in the Molasse Basin, (ii) drainage direction in the foreland, and (iii) folding of the Jura fold-and-thrust belt. b Pattern of sediment accumulation and erosion taken from Willett and Schlunegger (2010) that is based on thicknesses and erosion of well-sections illustrated in Fig. 2. These are for the east: Cuarny-1 $(\mathrm{CU})$, Courtion $(\mathrm{C})$ and Chappelle-1 $(\mathrm{CH})$; for the center: Altishofen-1 $(A)$, Boswil-1 $(B O)$ and Hünenberg-1 $(H \ddot{U})$; for the east: Lindau-1 $(L I)$, Kreuzlingen-1 $(K)$, Berligen-1 $(B)$ and Küsnacht-1 $(K \ddot{U})$; for the region surrounding the Subalpine Molasse: Rigi $(R)$, Linden-1 $(L)$ and Thun-1 $(T)$. c Chronology of basin erosion at Weiach (WE, Fig. 2) for the scenario that erosion started at $10 \mathrm{Ma}$ (Mazurek et al. 2006) and $5 \mathrm{Ma}$ (Cederbom et al. 2004). The latter history of erosion is based on data with a higher resolution and is thus preferred in this paper. d Pattern of sediment accumulation in circum-Alpine basins. The conversion of the Hay et al. (1992) data is based on a density of $2.65 \mathrm{~g} / \mathrm{cm}^{3}$. We considered the sediment budgets of basins that received sediment from the Central Alps only (i.e., Swiss Molasse, Rhine Graben, Rhône and Bresse Grabens, Rhône delta, North Sea; Hay et al. 1992; Kuhlemann 2000). Sediment discharge increased at $5 \mathrm{Ma}$, and the recycling of the Molasse deposits could explain this increase. Subsequent glaciations probably contributed to the enhancement of sediment flux during the Pleistocene. e Oxygen isotope curve of Zachos et al. (2001) used as proxy for climate change. All x-axes (time) are at the same scale. See text for further discussion 
Alpine forebulge. During the Late Pliocene, tensional subsidence of the southern parts of the Upper Rhine Graben resumed to continue to the present.

In the Bresse-Valence Graben (Figs. 1, 2), Cenozoic deposits reach a maximum thickness of 2,300 m (DebrandPassard and Courbouleix 1984). Sediment accumulation started with locally derived Middle Eocene fluvio-lacustrine deposits. Late Eocene and Early Oligocene series comprise several hundreds of meters thick successions of evaporites interbedded with fluvio-lacustrine limestones, marls, conglomerates and breccias that were deposited in a hydrologically closed environment. Late Oligocene series are developed in a marginal marine clastic facies that evolved into Oligocene to Early Miocene lacustrine limestones (Sissingh 2006b). Development of a mid-Burdigalian unconformity is related to uplift of the Vosges-Black Forest Arch (Dèzes et al. 2004; Ziegler and Dèzes 2007). Deposition of shallow marine sandstones and conglomerates followed a Serravallian transgression and lasted to the Messinian, when desiccation of the Mediterranean and associated base level lowering resulted in the erosion of previously deposited sediment. Pliocene accumulation of ca. 300-m-thick lacustrine marls and fluvio-deltaic clastics reflected a tensional reactivation of the Bresse Graben. Of these clastics, the 4.2- and 2.9-Ma-old Desnes-Forèt de Chaux Gravels had their source in the Central Alps and were shed into the Bresse Graben by the Aare-Doubs (Petit et al. 1996; Fejfar et al. 1998, see below). Tensional subsidence of the Bresse Graben continued during the Early Pleistocene and ceased around 1.4 Ma when the graben became uplifted and subjected to erosion (Rat 1978, 1984; Rocher et al. 2003; Dèzes et al. 2004).

\section{The drainage network}

During deposition of the OSM, sediments were shed into the Molasse Basin from the Alps as well as from the Vosges-Black Forest arch (Füchtbauer 1959; Kuhlemann and Kempf 2002; Sissingh 2006a; Ziegler and Fraefel 2009). The detritus from the Alps accumulated as braidplain conglomerates, floodplain marls and lacustrine carbonates. In more distal sites, these deposits interfingered with the meanderbelt sandstones of the 'Graupensandrinne' or 'Glimmersandschüttung' (Kuhlemann and Kempf 2002; Berger et al. 2005a, b). This dispersal system with sources farther to the east (e.g., the Bohemian massif) was located at the northern edge of the basin and had a west-directed discharge, linking the Molasse basin with the marine embayment of the Bresse, Valence and Gulf of Lyons Grabens until mid-Tortonian times.

The subsequent development of the drainage network (Fig. 5) was recently outlined by Ziegler and Fraefel
(2009), and reconstructions are based on Central Alpine detritus in the following locations: (i) the lower Aare valley (Geissberg) and on the eastern flank of the Black Forest (Eichberg, Blumberg) (Hofmann 1996; Villinger 1998; Villinger 2003), (ii) Early Pliocene deposits of the Bresse Graben (4.2- to 2.9-Ma-old 'Cailloutis de Desnes' and 'Sables de Neublans'; Petit et al. 1996; Fejfar et al. 1998), (iii) Early Pliocene Sundgau Gravels with a clear Central Alpine provenance north of the Jura (Giamboni et al. 2004a, b; Madritsch et al. 2010a), and (iv) Late Pliocene to Holocene fluvial clastics of Alpine origin in the Rhine Graben (Hagedorn and Boenigk 2008). Accordingly, during the Late Tortonian dispersion switched toward the northeast (Aare-Danube River) presumably as the folding of the Jura shifted the basin depocenter to the east. A major change occurred during the Early Pliocene when the northeast-directed AareDanube was captured in the easternmost parts of the Jura fold-and-thrust belt by the headwaters of the proto-Doubs River that flowed to the west of the Jura (Ziegler and Fraefel 2009). From 4.2 Ma onward, the Aare-Doubs dispersal system flowed along the northern margin of the Jura (Sundgau Gravels) to the Bresse Graben ('Sables de Neublans' and 'Cailloutis de Desnes'), and finally to the Mediterranean. The petrographic composition of these deposits, characterized by flysch and low-grade metamorphic quartzite clasts in the conglomerates, and the predominance of epidote minerals with admixture of zircon, tourmaline, hornblende and pyroxene in the heavy mineral suites of sandstones (Liniger 1966; Hofmann 1996; Villinger 1998; Madritsch et al. 2010a), are identical to the petrofacies of the OSM conglomerates at Napf (Fig. 2); (Matter 1964). Therefore, the Sundgau Gravels were either deposited by the same rivers as the central OSM units that had their sources in the Central Alps (Matter 1964; von Eynatten et al. 1999) or reflect recycled Molasse conglomerates. Interestingly, this change occurred nearly at the same time or shortly after erosion in the Molasse Basin started around $5 \mathrm{Ma}$ according to Cederbom et al. (2004; 2008). The last major changes in the dispersal pattern occurred about $2.9 \mathrm{Ma}$ when the Aare-Doubs system was deflected into the Rhine Graben (Fig. 5d). Evidence for this rerouting is a massive influx of Alpine heavy minerals into the Upper Rhine Graben from the latest Pliocene onward (Hagedorn 2004; Hagedorn and Boenigk 2008; Rolf et al. 2008). Ziegler and Fraefel (2009) proposed that a subsequent major change occurred around 1.7 Ma when the Alpine Rhine was captured by headward erosion and routed toward the Rhine Graben (Villinger 2003). However, an erosional hiatus between the Pliocene and Pleistocene (Villinger 1998) impedes the reconstruction (and thus confirmation) of these details. 
Fig. 5 Chronology and pattern of discharge in the Molasse Basin and in the Alps for various times: a $18-10 \mathrm{Ma}$, b $10-4.2 \mathrm{Ma}$, c $4.2-2.9 \mathrm{Ma}$, and d the present situation. Yellow colors indicate accumulation of Alpine-derived detritus. Modified after Ziegler and Fraefel (2009). See text for further explanations

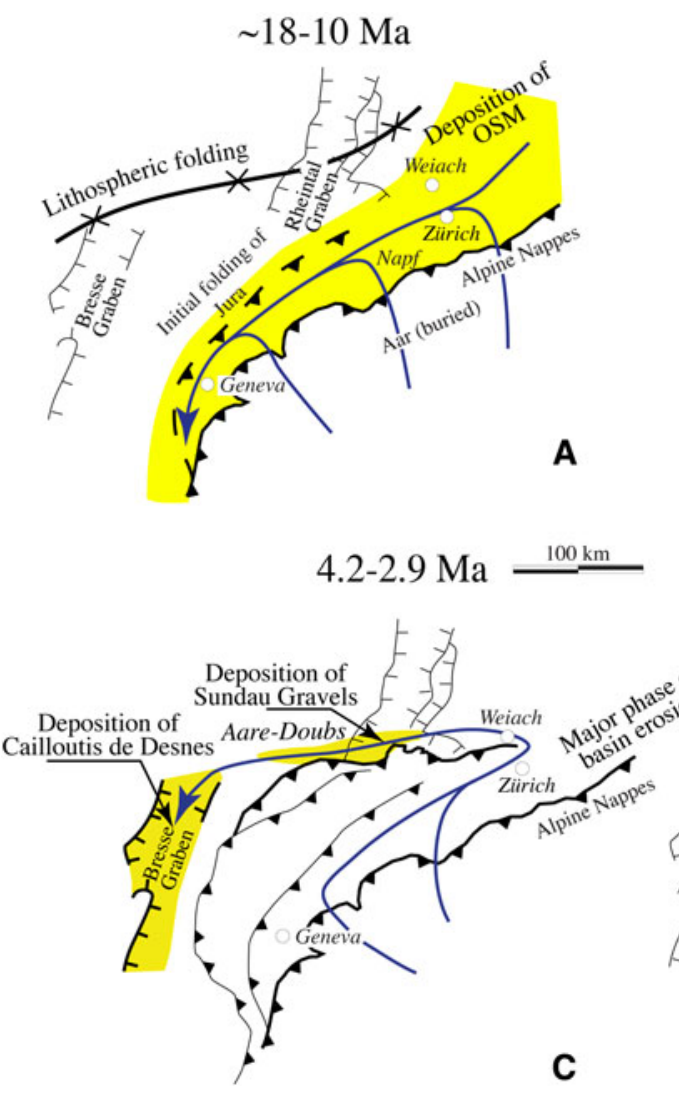

$\sim 10-4.2 \mathrm{Ma}$

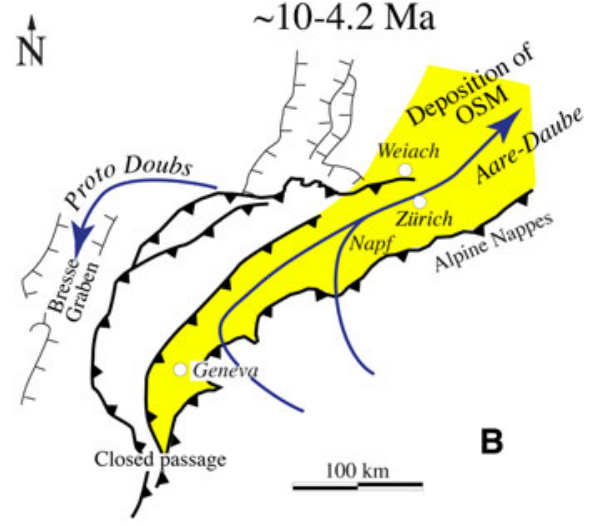

present

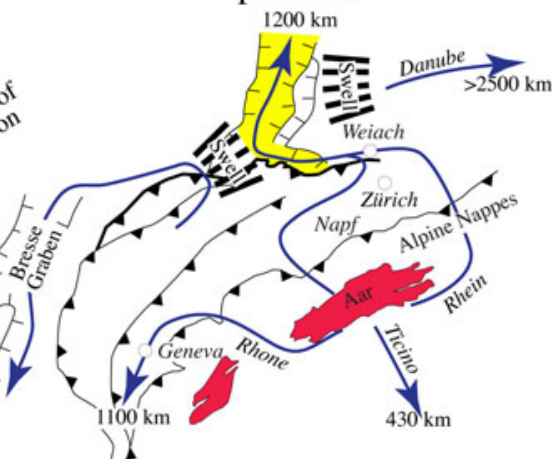

D

\section{Discussion}

Controls on changes of the drainage network between the Late Miocene and the presence

Following the interpretation of Ziegler and Fraefel (2009), we consider the erosion of the Molasse Basin to be a direct consequence of the re-routing of the Aare-Danube River toward the Bresse Graben, controlled by rifting (Fig. 5). Similar to Ziegler and Fraefel (2009), we propose that enhanced subsidence of the Bresse Graben, combined with the development of the topographic barrier of the Jura foldand-thrust belt, may underlay a phase of rapid headward erosion of the proto-Doubs and its tributaries, which drained the Vosges, Black Forest, and the Jura fold-andthrust belt (Fig. 5). This headward erosion culminated in the Early Pliocene cannibalization and redirection of the Aare drainage system. In addition, we propose that this redirection of the drainage initiated the major phase of erosion in the Molasse Basin. Our interpretation is based on three arguments: First, erosion of the Molasse increased at the same time (5 Ma; Cederbom et al. 2004, 2008) that the deposits of Central Alpine provenance began to accumulate in the Bresse Graben and along the northern margin of the Jura (Fig. 5c). However, because erosion of the Molasse Basin started prior to the inferred stream cannibalization, we think that some erosion occurred in response to shortening and related uplift of the Jura (Kuhlemann and Kempf 2002; Ziegler and Fraefel 2009) during its latest state of deformation. But we emphasize that in contrast to previous authors, we do not consider shortening of the Jura to have been the major driving force of erosion because the period of highest erosion rates postdates the major phase of Jura folding (Fig. 4). Furthermore, theoretical considerations (e.g., wedge mechanics, Willett and Schlunegger 2010) suggested that the erosion of the Molasse Basin could have slowed shortening rates in the Jura, potentially leading to the reactivation of thrusts beneath the Molasse Basin instead. Second, initial erosion of Molasse deposits occurred quickly from 5 to $2 \mathrm{Ma}$, but the rates decreased thereafter according to our model (see above, and Fig. 4c). This rather short phase of rapid erosion probably occurred by cannibalization and erosion of poorly consolidated rocks such as the Molasse deposits (Keller et al. 1990). Third, mean elevations of landscapes affected by river cannibalization were lowered (Fig. 6). In the Molasse Basin, the change from intra-basinal east-directed sediment transport to extra-basinal west-directed drainage at $4.2 \mathrm{Ma}$ shortened the pathway to sea level by at least $1,000 \mathrm{~km}$ or even more when considering the Bresse Graben lake as base level for the Aare-Doubs River (Ziegler and Fraefel 2009). Because steady-state mean elevations of a landscape 
increase with increasing distance from the base level, a reduction in the pathway to the base level ultimately results in erosion and lowering of mean elevations (Fig. 6). Considered in the context of some modern examples, the $1,000 \mathrm{~km}$ shorter length of the Aare-Doubs River corresponds to an elevation change of ca. $180 \mathrm{~m}$ for the Mississippi River, ca. $250 \mathrm{~m}$ for the Danube and the Nile Rivers and $>50 \mathrm{~m}$ for the Amazon River. Accordingly, the Pliocene cannibalization of the axial, northeast-directed drainage system in the Molasse Basin most likely resulted in a substantial lowering of the mean elevation during a relatively short time period. The amount of lowering of the mean topography in the Molasse Basin might have been $>200 \mathrm{~m}$, given the estimates for the modern Danube River. We acknowledge that sediment was not directly routed toward the Mediterranean or the Black Seas because a significant fraction was deposited along the way in the Pannonian Basin and the Bresse Graben. Nevertheless, some of the Alpine detritus was deposited in the Rhone delta and the Black Sea (Kuhlemann 2000; Hay et al. 1992), which indicates that these basins defined the ultimate base level.

We use standard hydrogeomorphological parameters extracted from modern European rivers and standard geomorphological equations to estimate the dependence of drainage basin relief on stream length in the Alps. Figure 6a shows the relationships between stream length $(L)$ and drainage area $(A)$ of all rivers originating in the Alps, including the Danube. These data allow the calibration of the exponent and the coefficient of Hack's relationships $A=a L^{b} \quad$ (Hack 1973; Flint 1974), where $a=0.0034$ and $b=2.53$ (Fig. 6). In addition, it has been shown that channel gradients $(S)$ also display a power law relationship to area, where $S=k_{\mathrm{s}} A^{-\theta}$ (Hack 1973). Using average steepness values $k_{\mathrm{s}}=26$ calculated for bedrock and alluvial Alpine streams (Norton et al. 2010a; 2010b) and a concavity $\theta=0.45$ for Alpine rivers (Korup 2006) and streams in active orogens in general (e.g., Whipple 2004; Safran et al. 2005; Wobus et al. 2006) allows the calculation of ideal stream profiles before and after stream capture (Fig. 6b). Accordingly, based on these parameters and equations, the integration of channel gradients $(S)$ due to ca. 1,000-km-long shortening of the stream (controlled by rifting in the Bresse Graben, see above) yielded an elevation drop ( $\Delta z$ ) of ca. $200 \mathrm{~m}$ (Fig. 6b). Recent studies (e.g., Ouimet et al. 2009) suggested that average channel steepness $\left(k_{\mathrm{s}}\right)$ and concavity $(\theta)$ values may be higher in active orogens. The effect in either of these cases would be an even larger erosional drop. Hence, the 200-m estimate used here is conservative.

The past 2.9-Ma re-routing of the rivers to the north subsequent to the deposition of the Sundgau Gravels is attributed to the resumption of rifting and subsidence of the southern Rhine Graben (Dèzes et al. 2004). As this change in the drainage direction increased the pathway to the terminal base level (which is the North Sea), it did not contribute to a further acceleration of erosion.

Implications for basin uplift

The reduction in the mean elevation of the Molasse Basin needs to be considered as the combined result of erosional unloading leading to a reduction in topography, and flexural accommodation of the crust resulting in uplift (Fig. 6b). In the simplest case where topographic loads are locally compensated (Airy isostasy) (Fig. 6c), the amount of subsidence $(y)$ is proportional to the ratio of densities of the floating $\left(\rho_{1}\right)$ and supporting mass $\left(\rho_{2}\right)$ :

$y=z \frac{\rho_{1}}{\rho_{2}}, \quad y^{\prime}=z-y=z \times\left(1-\frac{\rho_{1}}{\rho_{2}}\right)$.

The removal of mass with thickness $a$ (which corresponds to erosion) then yields:

$z^{\prime}=z-a \rightarrow y^{\prime \prime}=(z-a) \times\left(1-\frac{\rho_{1}}{\rho_{2}}\right)$.

Note that this simple calculation neglects the effects of elastic bending to loading of the downgoing plate. Nevertheless, according to this basic model, the amount of erosional unloading required to reduce the average topography by $>200 \mathrm{~m}$ is proportional to the density ratio between crust $\left(2.7 \mathrm{t} / \mathrm{m}^{3}\right)$ and mantle $\left(3.4 \mathrm{t} / \mathrm{m}^{3}\right)$ and amounts to $>1,000 \mathrm{~m}$ (Fig. 6b). This thickness is similar to the value obtained by Schegg et al. (1997); Mazurek et al. (2006); Cederbom et al. (2004, 2008) related to the erosion of the Molasse Basin. Note that if lithospheric strength (e.g., elastic thickness of $10 \mathrm{~km}$; Sinclair et al. 1991) is considered, this estimate could be reduced by up to $40 \%$ (Schlunegger et al. 1997). This does not, however, alter the interpretation that substantial erosion is required to reduce the mean topography by $>200 \mathrm{~m}$.

Earlier phases of drainage reversal, e.g., during the Burdigalian (from east- to west-directed) and during the Late Tortonian (from west- to east-directed), might also have resulted in erosion. The Burdigalian drainage reversal occurred during the deposition of the Upper Marine Molasse when the basin was slightly underfilled and no erosion occurred (Schlunegger et al. 2007). The Late Tortonian drainage reversal occurred during the deposition of the OSM, but would have resulted in sediment accumulation as the change from west- to east-directed increased the length of the flow path.

We realize that the inferred passage from active basin subsidence to active basin uplift by river erosion needs to be justified with more detail. As outlined above, rivers with lower basel levels or shorter path ways are more erosive 

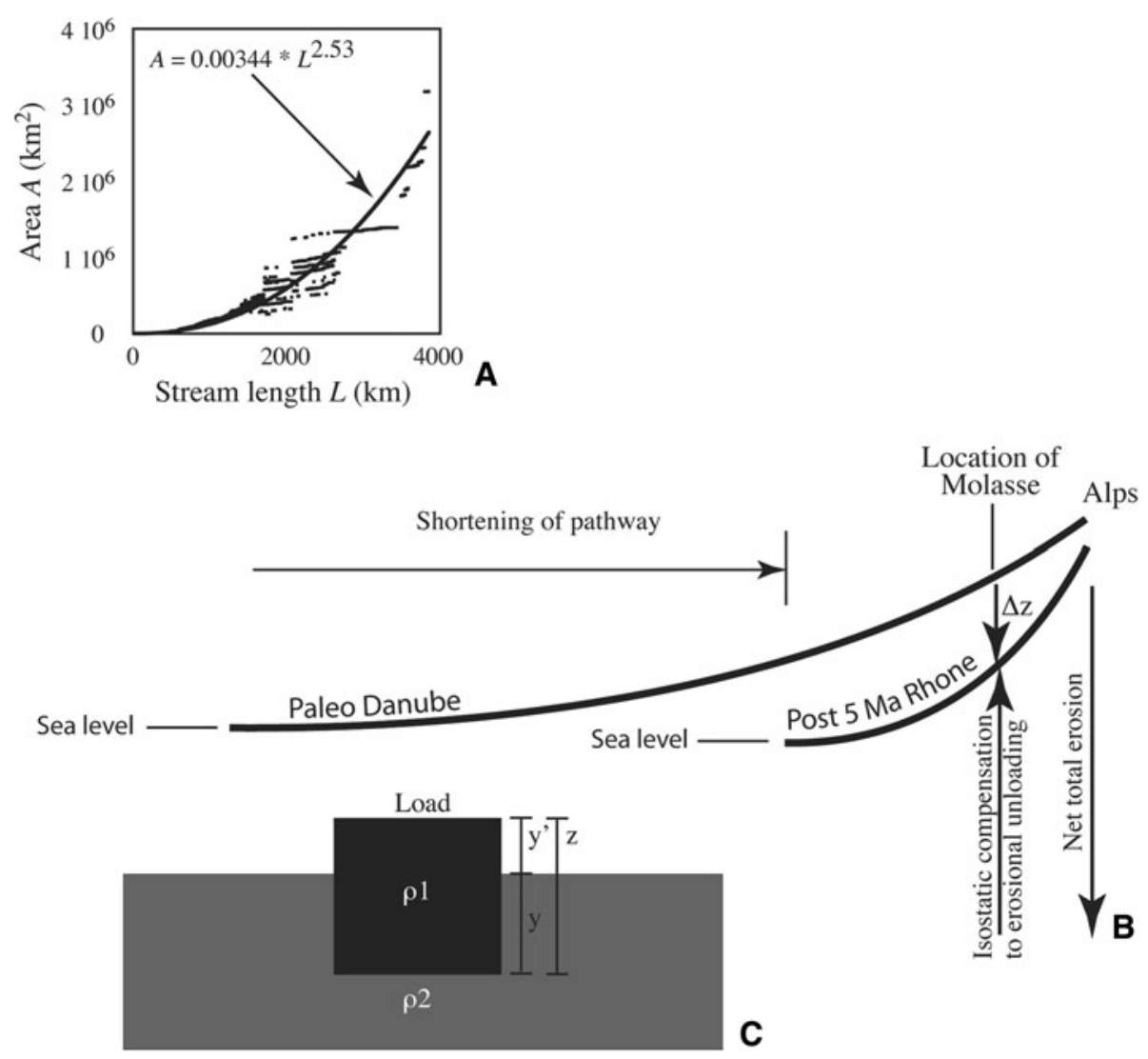

Fig. 6 Topographic lowering and related isostatic accommodation. a Relationships between stream length $(L)$ and drainage area $(A)$ of all rivers originating in the Alps including the Danube. These data allow the calibration of the exponent and the coefficient of Hack's relationships $A=a L^{b}$ (Hack 1973; Flint 1974), where $a=0.0034$ and $b=2.53$. b Sketch figure showing the effect due to shortening of the pathway. The reduction in the mean elevation of the Molasse

and, as a result, capture other streams. This has been proposed and shown in actively evolving landscapes (e.g., Willett et al. 2010) and is postulated here for the subsiding Molasse basin. Important for the latter situation is the ratio between the erosion rates of the cannibalizing river $(0.3-0.4 \mathrm{~mm} /$ year) and the flexural subsidence rates caused by orogenic loads $(<0.25 \mathrm{~mm} / \mathrm{year}$ during OSM times, Kempf and Matter 1999). The net effect was unloading of the Molasse Basin, shifting the basin from the state of subsidence to rebound.

The contribution of $12,000-24,000 \mathrm{~km}^{3}$ of recycled Molasse corresponds approximately to the increase in sediment discharge at the Miocene-Pliocene boundary (Fig. 4d). The onset of higher sediment discharge at ca. $5 \mathrm{Ma}$ can therefore be considered as the combined effect of stream cannibalization and rerouting of rivers, resulting in a lowering of mean elevations and isostatic accommodation to erosional unloading. This mechanism does not require a large climate fluctuation to explain the observed uplift and erosion. This point was already mentioned by
Basin then needs to be considered as the combined result of erosional unloading leading to reduction in topography, and flexural accommodation of the crust resulting in rock uplift. c Sketch figure showing the simplest case where topographic loads are locally compensated (Airy isostasy). Accordingly, the amount of subsidence $(y)$ is proportional to the ratio of densities of the floating $\left(\rho_{1}\right)$ and supporting mass $\left(\rho_{2}\right)$. See text for further details

Kuhlemann and Kempf (2002) who considered that the increase in sediment discharge after 5 Ma reflects strong erosion in the Alpine orogen and in the western part of the north Alpine foreland basin. This is advantageous because, as reported above, the climate transition at the MiocenePliocene boundary was gradual (Fig. 4e) and would not be able to trigger such changes unless a threshold condition was exceeded. At the moment, no convincing threshold has been suggested. In fact, measurements of ${ }^{10} \mathrm{Be}$-based denudation rates appear to refute a relationship between precipitation rates and erosion in the Alps (Willenbring and von Blanckenburg 2010; Norton et al. this volume).

The role of climate

Climate change presumably modified the sediment discharge pattern during the Late Pliocene and the Early Pleistocene. The benthic oxygen isotope record shows a large increase in global ice volume, with more than 100 oscillations between mild and cool climates since 
3 Ma (Zachos et al. 2001; Fig. 4e). The greatest ice volumes are assigned to the past 0.9 Myear, associated with an amplification in the 100ky cycle (Zhang et al. 2001). This also appears to be the case in the Alps with enhanced erosion since 0.9 Ma (Muttoni et al. 2003; Häuselmann et al. 2007). Repeated glaciations had a large effect on the morphology of the Alps, with the modern topography dominated by glacial and periglacial features (van der Beek and Bourbon 2008). The glacial overprints and the related transience of the Alpine landscape are presumably the most important drivers of Holocene erosion and the related isostatic accommodation (Norton et al. 2010a, b). We propose that whereas the Early Pliocene initiation of enhanced sediment discharge was most likely controlled by intrinsic processes in the Molasse Basin and was not driven by climate change, the continued Pleistocene acceleration of surface erosion was possibly driven by the high frequency of glacial advances, preventing the Alpine landscape from reaching an equilibrium.

Implications for understanding the last evolutionary stages of the Alps and the Molasse Basin

Numerous papers have addressed the issue of the relationship between the tectonic events in the Alps and the sedimentary and erosional processes in the Molasse Basin (Pfiffner 1986; Burkhard 1990; Burkhard and Sommaruga 1998; Sissingh 2006a, 2006b) and illustrated well-established correlations. Recently, Bonnet et al. (2007, 2008) explored the mechanical links between tectonic evolution, basin sedimentation and erosion based on analogue tapered wedge models for the evolution of foreland basin in conjunction with underplating of basement nappes. In general, these models show that the geometric and kinematic evolution of the wedge strongly depends on the amount of sediment shed into the foreland basin as well as the eroded volumes, both in the growing wedge and in the basin. Bonnet et al. $(2007,2008)$ emphasized that initiation and acceleration of upper crustal stacking and uplift of the External Massifs resulted exclusively from the convergence of Adria and Europe, irrespective of erosion rates. Also according to these models, a possible climate-driven increase in erosion rates would lead to an increase in exhumation rates of the External Massifs by focused deformation along a restricted, narrow deformation zone. The structural response would be the establishment of a duplex zone contrasting with the vertical uplift in the Alps (Fig. 2). The chronology of exhumation, with acceleration starting prior to $5 \mathrm{Ma}$ (Aar Massif), and the geometry of the External Massifs can be considered as the consequence of ongoing deformation and crustal accretion and does not necessarily point toward a climate forcing (see introduction). Furthermore, as outlined by Mosar (1999), thrusting in the External Massifs and the associated build up of topography most likely increased the Alpine taper to supercritical. According to this author, this situation led to the development of basement deformation as is still observed today in the region of the external Jura (Ustaszewski and Schmid 2007). Because erosion and accelerated recycling of the Molasse deposits since $5 \mathrm{Ma}$ reduced the loads of the foreland, we interpret that activation of basement thrusts particularly beneath the Molasse Basin and possibly the Jura occurred in order to restore the critical wedge (see also Willett and Schlunegger 2010). We see this mechanism as a possible explanation for deepseated earthquakes beneath the foreland (Deichmann 1992) and the Jura (Edel et al. 2006). Similarly, the backstepping of thrusting into the Subalpine Molasse could be considered as a consequence of Molasse unloading, although the chronology of thrusting needs to be further detailed.

\section{Conclusions}

This is an idea-driven paper with the aim to call for a more careful consideration of potential erosional drivers. In particular, we present a tectonic model that is capable of explaining the erosion of the Molasse without the need for a climate forcing. We propose, based on our synthesis of depositional and erosional processes in the Alps and surrounding basins in the north that:

- The major phase of erosion of the Molasse Basin can be considered as the consequence of drainage pattern changes without the need of a climate driver;

- The change in the drainage direction was probably controlled by tectonic activity in the Cenozoic European Rift System;

- Climate change imprinted the Alps with the onset of glaciations at the Pliocene-Pleistocene boundary at the earliest;

- The pattern and rates of exhumation in the External Massifs do not reveal the fingerprint of a particular climate or a climate change.

Accordingly, we see the need for a more careful treatment of both tectonic and climate forcing on the development of the Alps and the adjacent foreland basins. It is important to note that the major points that support our hypothesis are (i) information regarding the time (ca. $5 \mathrm{Ma}$ ) and magnitude of erosion in the Molasse (1,000-2,000 m) as calibrated by Cederbom et al. $(2004,2008)$, (ii) restorations of the drainage network and particularly the chronology of stream piracy as synthesized by Ziegler and Fraefel (2009) from various sources, and (iii) the use of a simple geomorphic and isostatic model that allows to estimate the amount of erosion and crustal rebound in response to stream 
cannibalization $(>1,000 \mathrm{~m})$. Further detailed thermo-chronometric data are needed to constrain (or reject) the idea presented here.

Acknowledgments This paper substantially benefited from fruitful discussions with Joachim Kuhlemann who independently developed the idea of the river cannibalization in the Molasse. Discussions with Charlotte Cederbom, Jean-Pierre Berger, Erik Frank and Sean Willett, and colleagues from KNE (Kommission für Nukleare Entsorgung) are kindly acknowledged. Kevin Norton calculated the slope-area relationships for the Alps and helped us with a scientifically sound solution. This research was supported by ESF funds for TopoEurope and the Swiss National Science Foundation (grant no. 20T021-120464/1).

\section{References}

Affolter T, Gratier J-P (2004) Map view retrodeform, ation of an arcuate fold-and-thrust belt: the Jura case. J Geophys Res 109:B03404. doi:10.1029/2002JB002270

Berger JP, Reichenbacher B, Becker D, Grimm M, Grimm K, Picot L, Storni A, Pirkenseer C, Schaefer A (2005a) Eocene-Pliocene time scale and stratigraphy of the Upper Rhine Graben (URG) and the Swiss Molasse Basin (SMB). Int J Earth Sci 94:711-731

Berger JP, Reichenbacher B, Becker D, Grimm M, Grimm K, Picot L, Storni A, Pirkenseer C, Schaefer A (2005b) Paleogeography of the Upper Rhine Graben (URG) and the Swiss Molasse Basin (SMB) from Eocene to Plicoene. Int J Earth Sci 94:697-710

Bonnet C, Malavielle J, Mosar J (2007) Interactions between tectonics, erosion, and sedimentation during the recent evolution of the Alpine orogen: analogue modeling insights. Tectonics 26: TC6016

Bonnet C, Malavieille J, Mosar J (2008) Surface processes versus kinematics of thrust belts: impact on rates of erosion, sedimentation, and exhumation-Insights from analogue models. Bull Geol France 179:297-314

Bourgeois O, Ford M, Diraison M, Le Carlier de Veslud C, Gerbault M, Pik R, Ruby N, Bonnet S (2007) Separation of rifting and lithospheric folding signatures in the NW-Alpine foreland. Int $\mathrm{J}$ Earth Sci 96:1003-1031

Braillard L (2006) Morphogenèse des vallées sèches du Jura tabulare d'Ajoie (Suisse): role de la fracturation et etude des remplissages quaternaries. $\mathrm{PhD}$ thesis, University of Fibourg, pp 224

Brink HJ, Burri P, Lunde A, Winhard H (1992) Hydrocarbon habitat and potential of Swiss and German Basin: a comparison. Eclogae Geol Helv 85:715-732

Bruch AA, Utescher T, Mosbrugger V, Gabrielyan I, Ivanov DA (2006) Late Miocene climate in the circum-Alpine realm-a quantitative analysis of terrestrial palaeofloras. Paleogeogr Paleoclimatol Palaeoecol 238:270-280

Burkhard M (1990) Aspects of the large-scale Miocene deformation in the most external part of the Swiss Alps (Subalpine Molasse to Jura fold belt). Eclogae Geol Helv 83:559-583

Burkhard M, Sommaruga A (1998) Evolution of the Western Swiss Molasse Basin: structural relations with the Alps and the Jura Belt. In: Mascle A, Puigdefabregas C, Luterbacher HP, Fernandez M (ed) Cenozoic Foreland Basins of Western Europe. Geol Soc Spec Publ 134: 279-298

Buxtorf A (1916) Prognosen und Befunde beim Hauensteinbasis und Grenchenbergtunnel und die Bedeutung der Letzteren für die Geologie der Jurabebirges. Verh Naturforsch Ges Basel 27:185-254

Carretier S, Nivière B, Giamboni M, Winter T (2006) Do river profiles record along-stream variations of low uplift rate? J Geophy Res 111:F02024
Cederbom C, Sinclair H, Schlunegger F, Rahn M (2004) Climate induced rebound and exhumation of the European Alps. Geology 32:709-712

Cederbom CE, Schlunegger F, Sinclair HD, van der Beek P (2008) Late Neogene climatic, tectonic and geodynamic forcing on the European Alps recorded by the erosion history of the North Alpine Foreland Basin. Geophys Res Abstr, 10 EGU2008-A01147

Cerling TE, Harris JM, MacFadden BJ, Leakey MG, Quade J, Eisenmann V, Ehleringer JR (1997) Global vegetation change through the Miocene/Pliocene boundary. Nature 389:153-158

Debrand-Passard S, Courbouleix S (1984) Synthèse géologique du Sud-Est de la France. Mém BRGM 126:16

Deichmann N (1992) Structural and rheological implications of lower-crustal earthquakes below northern Switzerland. Physics Earth Planet Inter 69:270-280

Dèzes P, Schmid SM, Ziegler PA (2004) Evolution of the European Cenozoic Rift System: interaction of the Alpine and Pyrenean orogens with their foreland lithosphere. Tectonophysics 389:1-33

Diem B (1986) Die Untere Meeresmolasse zwischen der Sanne (Westschweiz) und der Ammer (Oberbayern). Eclogae Geol Helv 9:493-559

Edel J-B, Whitechurch H, Diraison M (2006) Seismicity wedge beneath the Upper Rhine Graben due to Alpine backward push? Tectonophysics 428:49-64

Escher A, Beaumont C (1997) Formation, burial and exhumation of basement nappes at crustal scale: a geometric model based on the Western Swiss-Italian Alps. J Struct Geol 19:955-974

Escher A, Hunziker J-C, Marthaler M, Masson H, Sartori M, Steck A (1997) Geologic framework and structural evolution of the western Swiss-Italian Alps. In: Pfiffner OA, Lehner P, Heitzmann P, Müller S, Steck A (ed) Deep structure of the Swiss Alps: results from the National Research Program 20 (NRP 20). Schweiz geol Komm, Birkhäuser, Basel: 205-221

Fejfar O, Heinrich DW, Lindsay EH (1998) Updating the Neogene Rodent biochronology in Europe. In: Van Kolfschoten T, Gibbard PL (ed) The dawn of the quaternary. Mededelingen Nederlands Instituut voor Toegepaste Geowetenschappen, 60: 533-554

Flint JJ (1974) Stream gradient as a function of order, magnitude, and discharge. Water Resour Res 10:969-973

Ford M, Lickorish WH (2004) Foreland basin evolution around the western Alpine Arc. Geol Soc London Spec Publ 221:39-63

Füchtbauer H (1959) Zur Nomenklatur der Sedimentgesteine. Erdöl Kohle 12:605-613

Fügenschuh B, Schmid SM (2003) Late stages of deformation and exhumation of an orogen constrained by fission-track data: a case study in the Western Alps. Geol Soc Amer Bull 115:1425-1440

Geissert F, Menillet F, Farjanel G (1976) Les alluvions rhénanes plioquaternaires dans le départment du Bas-Rhin. Sci Géol Bull Strasbourg 29:121-170

Giamboni M, Wetzel A, Nivière B, Schumacher M (2004a) PlioPleistocene folding in the southern Rhinegraben recorded by the evolution of the drainage network (sundgau area; northwestern Switzerland and France). Eclog Geol Helv 97:17-31

Giamboni M, Ustaszewski K, Schmid SM, Schumacher M, Wetzel A (2004b) Plio-Pleistocene reactivation of Paleozoic and Paleogene structures in the Rhine-Bresse transform zone (northern Switzerland and eastern France). Int J Earth Sci 93:207-223

Gorin GE, Signer C, Amberger G (1993) Structural configuration of the western Swiss Molasse Basin as defined by reflection seismic data. Eclogae Geol Helv 86:693-716

Guellec S, Mugnier JL, Tardy M, Roure F (1990) Neogene evolution of the western Alpine foreland in the light of ECORS data and balanced cross-section. Mem Soc geol France 156:165-184 
Hack JT (1973) Stream profile analysis and stream-gradient index. U.S. Geological Survey J Res 1:421-429

Hagedorn E-M (2004) Sedimentpetrographie und Lithofazies der jungtertiären und quartären Sedimente im Oberrheingebiet. PhD. thesis, University of Cologne

Hagedorn E-M, Boenigk W (2008) the Pliocene and quaternary sedimentary and fluvial history in the Upper Rhine Graben based on heavy mineral analyses. Netherlands J Geosci 87:21-32

Haldemann EG, Haus H, Bolliger H, Liechti W, Rutsch RF, Della Valle G (1980) Geologischer Atlas der Schweiz 1:25,000, Blatt 1188 Eggiwil (Nr 75). Schweiz geol Komm

Haus H (1937) Geologie der Gegend von Schangnau im oberen Emmental (Kt. Bern). Ein Beitrag zur Stratigraphie und Tektonik der subalpinen Molasse und des Alpenrandes. Beitr geol Karte Schweiz NF 75. Schweiz geol Komm, pp 93

Häuselmann P, Granger DE, Jeannin PY, Lauritzen SE (2007) Abrupt glacial valley incision at $0.8 \mathrm{Ma}$ dated from cave deposits in Switzerland. Geology 35:143-146

Hay WW, Wold CN, Herzog JM (1992) Preliminary mass-balanced $3 \mathrm{D}$ reconstructions of the Alps and surrounding areas during the Miocene. In: Pflug R, Harbaugh JW (ed) Computer graphics in geology, threedimensional computer graphics in modeling geologic structures and simulating geologic processes. Lecture Notes Earth Science 41:99-100

Hinsken S, Ustaszewski K, Wetzel A (2007) Graben width controlling synrift sedimentation: the Paleogene southern Upper Rhine Graben as an example. Int J Earth Sci 96:979-1002

Hofmann F (1996) Zur plio-pleistozänen Landschaftsgeschichte im Gebiet Hochrhein-Wutach-Randen-Donau. Geomorphologische Ueberlegungen und sedimenpetrographische Befunde. Eclogae Geol Helv 89:1023-1041

Homewood P, Lateltin O (1988) Classic swiss clastics (flysch and molasses). The alpine connection. Geodinamica Acta 2:1-11

Homewood P, Allen PA, Williams GD (1986) Dynamics of the Molasse Basin of western Switzerland. In: Allen PA, Homewood P (ed) Foreland basins. Int Assoc Sedimentol Spec Publ 8: 199-217

Kälin B, Rybach L, Kempter EHK (1992) Rates of deposition, uplift and erosion in the Swiss Molasse Basin, estimated from sonicand density-logs. Bull Ver Schweiz Pet Geol Ing 72:9-22

Keller B (1989) Fazies und Stratigraphie der Oberen Meeresmolasse (Unteres Miozän) zwischen Napf und Bodensee. Unpublished $\mathrm{PhD}$ thesis, University of Bern, pp 277

Keller B, Bläsi HR, Platt NH, Mozley PS, Matter A (1990) Sedimentäre Architektur der distalen Unteren Süsswassermolasse und ihre Beziehung zur Diagenese und den petrophysikalischen Eigenschaften am Beispiel der Bohrungen Langenthal. Geol Berichte Landeshydrol -Geol 13:100

Kempf O, Matter A (1999) Magnetostratigraphy and depositional history of the Upper Freshwater Molasse (OSM) of eastern Switzerland. Eclogae Geol Helv 92:97-103

Kissling E, Schmid SM, Lippitsch R, Ansorge J, Fügenschuh B (2006) Lithosphere structure and tectonic evolution of the Alpine arc: new evidence from high-resolution teleseismic tomography. In: Gee DG, Stephenson RA (ed) European lithosphere dynamics. Geol Soc London Mem 32: 129-145

Korup O (2006) Rock-slope failure and the river long profile. Geology 34:45-48

Kuhlemann J (2000) Post-collisional sediment budget of circumAlpine basins (Central Europe). Mem Ist Geol Miner Univ Padova 52:91

Kuhlemann J, Kempf O (2002) Post-Eocene evolution of the North Alpine Foreland Basin and its response Alpine tectonics. Sediment Geol 152:45-78

Kuhlemann J, Frisch W, Dunkl I, Szekely B (2001) Quantifying tectonic versus erosive denudation by the sediment budget; the Miocene core complexes of the Alps. Tectonophysics 330:1-23
Laubscher HP (1961) Die Fernschubhypothese der Jurafaltung. Eclogae Geol Helv 54:221-282

Laubscher HP (1986) The eastern Jura: relations between thinskinned and basement tectonics, local and regional. Geol Rundsch 75:535-553

Laubscher HP (1992) Jura kinematics and the Molasse basin. Eclogae Geol Helv 85:653-675

Liniger H (1966) Das Plio-Altpleistozäne Flussnetz des Nordschweiz. Regio Basiliensis 7:158-177

Madritsch H, Fabbri O, Hagedorn E-M, Preusser F, Schmid S, Zielger PA (2010a) Feedback between erosion and active deformation: geomorphic constraints from the frontal Jura fold-and-thrust belt (eastern France). Int $\mathbf{J}$ Earth Sci (in press)

Madritsch H, Preusser F, Fabbri O, Bichet V, Schlunegger F, Schmid S (2010b) Syn-erosional Quaternary folding and fluvial meanders in the Jura Mountains; Estimates of uplift rates and geodynamic implications. Terra Nova (in press)

Matter A (1964) Sedimentologische Untersuchungen im östlichen Napfgebiet (Entlebuch-Tal der Grossen Fontanne, Kt. Luzern). Eclogae Geol Helv 57:315-428

Matter A, Homewood P, Caron C, Rigassi D, Van Stujivenberg J, Weidmann M, Winkler W (1980) Flysch and molasse of western and central Switzerland. In: Trümpy R (ed) Geology of Switzerland, a guidebook, Part B, Excursions. Schweiz Geol Komm: 261-293

Mazurek M, Hurford A, Leu W (2006) Unravelling the multi-stage burial history of the Swiss Molasse basin: integration of apatite fission track, vitrinite reflectance and biomarker isomerisation analysis. Basin Res 18:27-50

Michalski I, Soom M (1990) The Alpine thermo-tectonic evolution of the Aar and Gotthard massifs, Central Switzerland: fission track ages on zircon and apatite and K-Ar mica ages. Schweiz Mineral Petrogr Mitt 70:373-387

Monnier F (1982) Thermal diagenesis in the Swiss Molasse basin: implications for oil generation. Can J Earth Sci 19:328-342

Mosar J (1999) Present-day and future tectonic underplating in the western Swiss Alps: reconciliation of basement/wrench-faulting and décollement folding of the Jura and Molasse basin in the Alpine foreland. Earth Planet Sci Lett 173:143-155

Mosar J, Stampfli GM, Girod F (1996) Western Préalpes médianes: timing and structure. A review. Eclogae Geol Helv 89:389-425

Müller WH, Näf H, Graf HR (2002) Geologische Entwicklung der Nordwestschweiz. Neotektonik und Langzeitszenarien Zürcher Weinland. NAGRA Techn Bericht, Wettingen, NZB 99-08, p 237

Muttoni G, Carcano C, Garzanti E, Ghielmi M, Piccin A, Pini R, Rogledi S, Sciunnach D (2003) Onset of major Pleistocene glaciations in the Alps. Geology 31:989-992

Norton KP, Abbühl L, Schlunegger F (2010a) Glacial conditioning as an erosional driving force in the Central Alps. Geology, in review

Norton KP, von Blanckenburg F, DiBiasi R, Schlunegger F, Kubik PW (2010b) Strong lithologic imprint on basin morphology and denudation in the Eastern and Southern European Alps. Int $\mathbf{J}$ Earth Sci (in review)

Ouimet WB, Whipple KX, Granger DE (2009) Beyond threshold hillslopes: channel adjusment to base-level fall in tectonically active mountain ranges. Geology 37:579-582

Persaud M, Pfiffner OA (2004) Active deformation in the eastern Swiss Alps: post-glacial faults, seismicity and surface uplift. Tectonophys 385:59-84

Petit C, Campy M, Chaline J, Bonvalot J (1996) Major palaeohydrographic changes in Alpine foreland during the PliocenePleistocene. Boreas 25:131-143

Pfiffner OA (1986) Evolution of the north Alpine foreland basin in the central Alps. In: Allen PA, Homewood P (ed) Foreland basins. Int Assoc Sedimentol Spec Publ 8: 219-228 
Pfiffner OA, Sahli S, Stäuble M (1997a) Structure and evolution of the external basement massif (Aar, Aiguilles Rouges/Mt. Blanc). In: Pfiffner OA, Lehner P, Heitzmann P, Müller S, Steck A (eds) Deep structure of the Swiss Alps: results from the National Research Program 20 (NRP 20). Schweiz geol Komm. Birkhäuser, Basel, pp 139-153

Pfiffner OA, Erard PF, Stäuble M (1997b) Two cross sections through the Swiss Molasse basin. In: Pfiffner OA, Lehner P, Heitzmann P, Müller S, Steck A (ed) Deep structure of the Swiss Alps: results from the National Research Program 20 (NRP 20). Schweiz geol Komm, Birkhäuser, Basel, 139-153: 64-72

Rahn MK, Selbekk R (2007) Absolute dating of the youngest sediments of the Swiss Molasse basin by apatite fission track analysis. Swiss J Geosci 100:137-381

Rat P (1978) Les phases tectoniques au Tertiaire dans le Nord du Fossé bressan et ses marges bourguignonnes en regard des systèmes d'érosion et de sédimentation. CR Soc Géol Fr pp 231-234

Rat P (1984) Une approche de l'environnement structural et morphologique du Pliocène et du Quaternaire bressans. Géol Fr 3:185-196

Rocher M, Chevalier F, Petit C, Guiraud M (2003) Tectonics of the Northern Bresse region (France) during the Alpine cycle. Geodin Acta 16:131-147

Rolf C, Hambach U, Weidenfeller M (2008) Rock and palaeomagnetic evidence for the Plio Pleistocene palaeoclimatic change recorded in the Upper rhine Graben sediments (core Ludwigshafen-Parkinsel). Netherlands J Geosci 87:41-50

Rosenberg CL, Berger A (2009) On the causes and modes of exhumation and lateral growth of the Alps. Tectonics 28: TC6001

Sadler PM (1999) The influence of hiatuses on sediment accumulation rates. Georesearch Forum 5:15-40

Safran EB, Biermann PR, Aalto R, Dunne T, Whipple KX, Caffee M (2005) Erosion rates driven by channel network incision in the Bolivian Andes. Earth Surf Process Landforms 30:1007-1024

Schegg R (1993) Thermal maturity and history of sediments in the North Alpine Foreland Basin (Switzerland, France). Publ Dept Geol Paleonol 15:1-194

Schegg R, Leu W (1998) Analysis of erosion events and palaeotherman gradients in the North Alpine Foreland Basin of Switzerland. In: Düppenbecker SJ, Iliffe JE (ed) Basin modelling: practice and progress. Geol Soc London Spec Publ 141: 137-155

Schegg R, Leu W, Cornford C, Allen P (1997) New coalification profies in the Molasse Basin of Western Switzerland: Implications for the thermal and geodynamic evolution of the Alpine foreland. Eclogae Geol Helv 90:79-96

Schlunegger F, Jordan TE, Klaper EM (1997) Controls of erosional denudation in the orogen on foreland basin evolution: the Oligocene central Swiss Molasse Basin as an example. Tectonics 16:823-840

Schlunegger F, Rieke-Zapp D, Ramseyer K (2007) Possible environmental effects on the evolution of the Alps-Molasse Basin system. Swiss J Geosc 100:383-405

Schmid SM, Pfiffner OA, Froitzheim N, Schönborn G, Kissling E (1996) Geophysical-geological transect and tectonic evolution of the Swiss-Italian Alps. Tectonics 15:1036-1064

Schmid SM, Fügenschuh B, Kissling E, Schuster R (2004) Tectonic map and overall architecture of the Alpine orogen. Eclogae Geol Helv 97:93-117

Sinclair HD, Allen PA (1992) Vertical versus horizontal motions in the Alpine orogenic wedge: stratigraphic response in the foreland basin. Basin Res 4:215-232

Sinclair HD, Coakley BJ, Allen PA, Watts AB (1991) Simulation of foreland fasin stratigraphy using a diffusion model of Mountain belt uplift and erosion: an example from the Central Alps, Switzerland. Tectonics 10:599-620

Sissingh W (1998) Comparative Tertiary stratigraphy of the Rhine Graben, Bresse Graben and Molasse Basin: correlation of Alpine foreland events. Tectonophysics 300:249-284

Sissingh W (2006a) Syn-kinematic palaeogeographic evolution of the West European Platform: correlation with Alpine plate collision and foreland deformation. Netherlands J Geosc 85:131-180

Sissingh W (2006b) Kinematic sequence stratigraphy of the European Cenzoic Rift System and Alpine Foreland Basin: correlation with Mediterranean and Atlantic plate-boundary events. Netherlands J Geosc 85:77-129

Sommaruga A (1997) Geology of the Central Jura and the Molasse Basin: new insight into an evaporite-based foreland fold and thrust belt. Mém Soc Neuchâteloise Sci Nat 12:176

Sommaruga A (1999) Décollement tectonics in the Jura forleland fold-and-thrust belt. Mar Petrol Geol 16:111-134

Strunck P, Matter A (2002) Depositional evolution of the western Swiss Molasse. Eclogae Geol Helv 95:197-222

Ustaszewski M, Pfiffner OA (2008) Neotectonic faulting, uplift and seismicity in the central and western Swiss Alps. In: Siegesmund $\mathrm{S}$, Fügenschuh B, Froitzheim N (ed) Tectonic aspects of the Alpine-Dinaride-Carpathian system. Geol Soc London Spec Publ 298: 231-249

Ustaszewski K, Schmid S (2007) Latest Pliocene to recent thickskinned tectonics at the Upper Rhine Graben-Jura Mountains junction. Swiss J Geosc 100:293-312

Van der Beek P, Bourbon P (2008) A quantification of the glacial imprint on 302 relief development in the French western Alps. Geomorphology 97:52-303

Vernon AJ, van der Beek P, Sinclair HD, Rahn MK (2008) Increase in late Neogene denudation of the Europan Alps confirmed by analysis of a fission track thermochronology database. Earth Planet Sci Lett 270:316-329

Vernon AJ, van der Beek P, Sinclair HD (2009) Spatial correlation between long-term exhumation rates and present-day parameters in the western European Alps. Geology 37:859-862

Villinger E (1998) Zur Flussgeschichte von Rhein und Donau in Südwestdeutschland. Jb Mitt Oberrhein Geol Ver NF 80:361-398

Villinger F (2003) Zur Paläogeographie von Alpenrhein und oberer Donau. Z Deutsch geol Ges 154:193-253

Vollmayr T, Wendt A (1987) Die Erdgasbohrung Entlebuch-1, ein Tiefenaufschluss am Alpennordrand. Bull Ver Schweiz Pet Geol Ing 53:67-79

Von Eynatten H, Schlunegger F, Gaupp R, Wijbrans JR (1999) Exhumation of the Central Alps: evidence from 40Ar/39Ar laserprobe dating of detrital white micas from the Swiss Molasse Basin. Terra Nova 11:284-289

Von Hagke C, Cederbom C, Lindow J, Oncken O, Schlunegger F (2010) Post $5 \mathrm{Ma}$ thrusting in the Northern Alpine Foreland Basin-insights from structural geology and new (U-Th)/He and Fission Track data. Geophys Res Abstr, 12 EGU2010-8858-1

Whipple KX (2004) Bedrock rivers and the geomorphology of active orogens. Ann Rev Earth Planet Sci Lett 32:151-185

Willenbring JK, von Blanckenburg F (2010) Long-term stability of global erosion rates and weathering during late-Cenozoic cooling. Nature 465:211-214

Willett SD, Schlunegger F (2010) The last phase of deposition in the Swiss Molasse Basin: from foredeep to negative-alpha basin. Basin Res, doi: 10.1111/j.1365-2117.2009.00435.x

Willett SD, Schlunegger F, Picotti V (2006) Messinian climate change and erosional destruction of the central European Alps. Geology 34:613-616

Willett SD, Braun J, Hermann F (2010) A new surface-process model for landscape evolution at a mountain belt scale. Geophys Res Abstr, 12 EGU2010-9403 
Wobus C, Whipple KX, Kirby E, Snyder E, Johnson J, Spyropolou K, Crosby B, Sheehan D (2006) Tectonics from topography: Procedures, promise, and pitfalls. In: Willett SD, Hovius N, Brandon MT, Fisher DM (ed) Tectonics, climate, and landscape evolution. Geolog Soc Amer Spec Paper 398: 55-74

Zachos J, Pagani M, Sloan L, Thomas E, Billups K (2001) Trends, rhythms, and aberrations in global climate $65 \mathrm{Ma}$ to present. Science 292:686-693

Zhang P, Molnar P, Downs WR (2001) Increased sedimentation rates and grain sizes 2-4 Myear ago due to the influence of climate change on erosion rates. Nature 410:891-897

Ziegler PA (1992) European Cenozoic rift system. Tectonophysics 208:91-111

Ziegler PA (1994) Cenozoic rift system of western and central Europe: an overview. Geol Mijnbouw 73:99-127
Ziegler PA, Dèzes P (2005) Evolution of the lithosphere in the area of the Rhine Rift system. Int J Earth Sci 94:594-614

Ziegler PA, Dèzes P (2007) Cenozoic uplift of Variscan Massifs in the Alpine foreland. Global planet. Change 58:237-269

Ziegler PA, Fraefel M (2009) Response of drainage systems to Neogene evolution of the Jura fold-thrust beld and Upper Rhein Graben. Swiss J Geosci 102:57-75

Ziegler PA, Bertotti G, Cloetingh S (2002) Dynamic processes controlling foreland development: the role of mechanical (de)coupling of orogenic wedges and forelands. In: Bertotti G, Schulmann K, Cloetingh S (ed), Continental collision and the tectono-sedimentary evolution of Forelands. Europ Geophys Soc Stephan Mueller Spec Publ 1: 29-91 